\title{
LATE ANEURYSM RELAPSE AFTER MICROSURGICAL TREATMENT OF MIDDLE CEREBRAL ARTERY ANEURYSM: A CASE REPORT AND LITERATURE REVIEW OF TREATMENT OPTIONS
}

\author{
Krešimir Rotim ${ }^{1,2,3}$ Marina Raguž ${ }^{4}$, Ante Rotim $^{4}$, Bruno Splavski ${ }^{1,2,3,5}$ and Vladimir Kalousek ${ }^{6}$ \\ ${ }^{1}$ Department of Neurosurgery, Sestre milosrdnice University Hospital Centre, Zagreb, Croatia; \\ ${ }^{2}$ Josip Juraj Strossmayer University of Osijek, Faculty of Medicine, Osijek, Croatia; \\ ${ }^{3}$ University of Applied Health Sciences, Zagreb, Croatia; \\ ${ }^{4}$ Department of Neurosurgery, Dubrava University Hospital, Zagreb, Croatia; \\ 5osip Juraj Strossmayer University of Osijek, School of Dental Medicine and Health, Osijek, Croatia; \\ ${ }^{6}$ Department of Radiology, Sestre milosrdnice University Hospital Centre, Zagreb, Croatia
}

\begin{abstract}
SUMMARY - Recurrence of intracranial aneurysm after initial microsurgical or endovascular treatment is uncommon. Although the exact etiology remains unknown, recurrent aneurysms may be observed in surgical patients with big and multiple aneurysms, arterial hypertension, non-atherosclerotic cerebrovascular arteriopathies, as well as in those with a familial history of the disease. Such recurrence can occur over a wide period ranging from several months to years after the initial aneurysm treatment. Still, the occurrence delayed by more than 20 years is rather unusual. Herein, we present a case of a 70-year-old female patient who developed late intracranial aneurysm relapse 30 years after successful microsurgical clipping of the middle cerebral artery aneurysm. We also provide a brief review of relevant literature, discussing the etiology and pathophysiology of aneurysm reappearance, as well as different treatment options available. In conclusion, one should always consider the possibility of intracranial aneurysm recurrence regardless of the mode and time of primary surgery. In such a case, a multidisciplinary management approach using flow diverting endovascular techniques is advised in selected patients.
\end{abstract}

Key words: Aneurysm, intracranial; Late recurrence; Treatment options, microsurgical and endovascular

\section{Introduction}

Recurrence of intracranial aneurysm after primary microsurgical or endovascular aneurysm treatment is unusual. The first report of such a relapse appeared in $1964^{1}$. Since then, the possibility of aneurysm recurrence after successful initial treatment has remained

Correspondence to: Bruno Splavski, $M D, P h D$, Department of Neurosurgery, Sestre milosrdnice University Hospital Centre, Vinogradska c. 29, HR-10000 Zagreb, Croatia

E-mail: splavuno@gmail.com

Received June 18, 2020, accepted August 20, 2020 one of the concerns of long-term follow-up. The accurate incidence remains a matter of debate, with annual rates ranging from $0.23 \%$ to $4.15 \%{ }^{2-7}$. It can occur over a wide period ranging from several months to years after successful initial aneurysm treatment ${ }^{8,9}$. Yet, the occurrence delayed by more than 20 years is rather unusual ${ }^{4,7}$.

Although the risk of aneurysm recurrence remains vague, several factors such as arterial hypertension, smoking, female gender, aneurysm size and multiplicity, non-atherosclerotic cerebrovascular arteriopathies (fibromuscular dysplasia, inherited collagen disorders), 


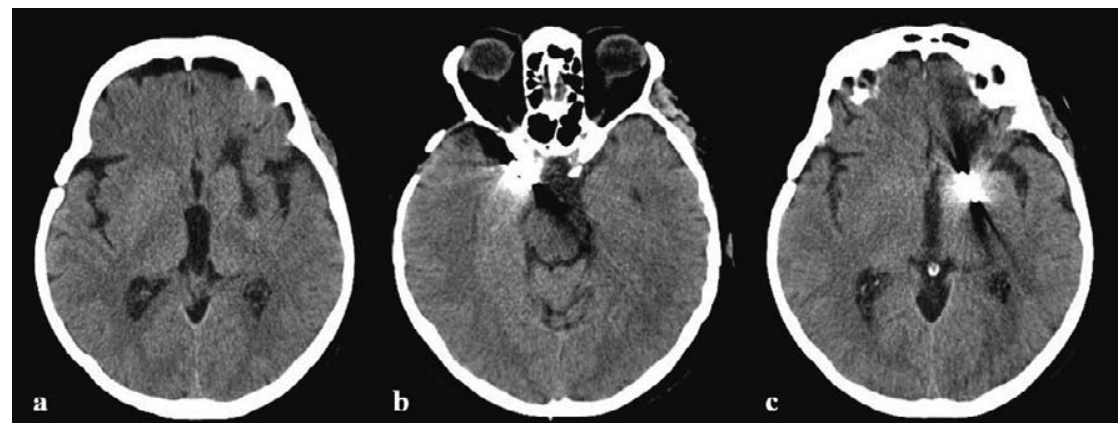

Fig. 1. Axial computed tomography of the brain revealing a hypodense zone and structurally altered parenchyma in the left basal ganglia without signs of acute bemorrhage (a), as well as metal foreign body artifacts from the previous microsurgical clip occlusion of the right internal carotid artery aneurysm (b), and left ruptured middle cerebral artery aneurysm (c).
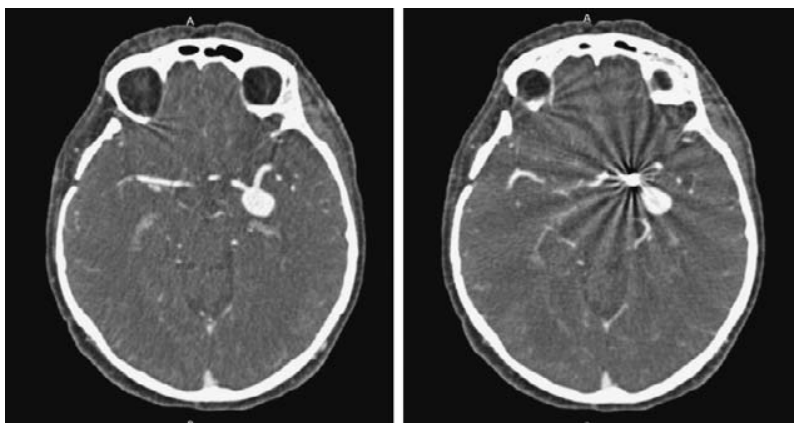

Fig. 2. Axial computed tomographic angiography showing extensive de novo aneurysm formation on M1 segment of the left middle cerebral artery, measuring $16 \mathrm{~mm}$ in diameter, after clipping.

and family history of the disease could be associated with its higher prevalence ${ }^{4,7,10-12}$. However, the physiopathology of aneurysm relapse, as well as the interaction of various risk factors remain controversial.

Aneurysm recurrence after microsurgical treatment has been reported previously, although neck clipping seemed to be associated with higher rates of complete aneurysm occlusion than various endovascular procedures $^{1,13}$.

Herein, we report on a case of a 70-year-old female in whom a delayed brain aneurysm relapse occurred 30 years after primary successful microsurgical clipping of the middle cerebral artery (MCA) aneurysm. We also provide a brief review of relevant literature, discussing the etiology and pathophysiology of intracranial aneurysm recurrence, as well as different treatment options available.

\section{Case Report}

A 70-year-old female patient was admitted to the hospital due to symptomatic epileptic seizure, loss of consciousness and consequential head trauma. The patient denied previous epileptic symptomatology and had a history of arterial hypertension. She was also a fervent smoker, having a positive family history of the disease, since her first female cousin suffered a ruptured intracranial aneurysm of unknown location and was also operated on.

The patient was diagnosed with multiple intracranial aneurysms 30 years before and underwent surgery due to the left-sided ruptured MCA aneurysm on M1 segment and right-sided supraclinoid internal carotid artery unruptured aneurysm, which were both microsurgically treated by bilateral pterional osteoplastic craniotomy and selective clipping. Her postoperative condition was uneventful and she recovered successfully afterwards.

Following the asymptomatic hiatus of 30 years post-surgery, she suffered an epileptic seizure with a consequential postictal loss of consciousness and minor head trauma. Afterwards, she developed mild right hemiparesis and dysesthesia of the right lower limb, so she was admitted to the hospital.

Following admission, initial computerized tomography $(\mathrm{CT})$ brain scans revealed a hypodense zone and structurally altered brain parenchyma in the left basal ganglia without signs of acute hemorrhage (Fig. 1 a), as well as metal foreign body artifacts (microsurgical 


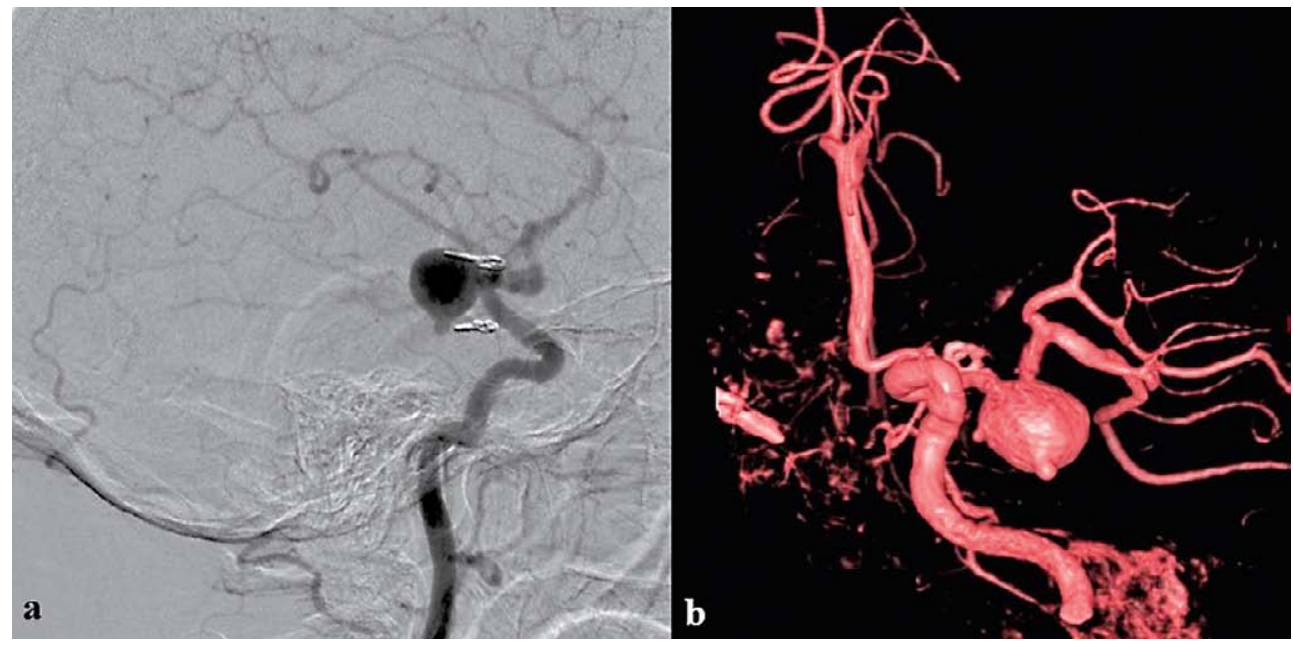

Fig. 3. Cerebral digital subtraction angiography (a), and $3 D$ angiography (b), confirming the aneurysm fundus revascularization after correct placement of two aneurysmal clips.

clips) from previous surgeries (Fig. $1 \mathrm{~b}, \mathrm{c}$ ). Axial CT angiography (CTA) of the cerebral vessels revealed extensive aneurysm recurrence on the M1 segment of the left MCA after the initial clipping, measuring 16 $\mathrm{mm}$ in diameter (Fig. 2). The patient underwent leftsided pterional re-craniotomy, aneurysm neck remodeling and additional clip placement.

Early postoperative brain CT revealed a hyperdense zone behind the newly placed clip, indicating mild left-sided hemorrhage in the zone of clipping, which was a concern for pooling of blood. Thus, digital subtraction cerebral angiography (DSA) (Fig. 3 a) and 3D CT angiography (Fig. $3 \mathrm{~b}$ ) were performed, showing slow filling of the aneurysm sac proximal to the newly placed clip, and confirming the aneurysm fundus revascularization.

Therefore, after pre-procedural antiplatelet dual therapy, the patient underwent endovascular treatment consisting of a novel flow-diverter placement through a 0.017 microcatheter, Silk Vista Baby (SVB), which was positioned throughout the M1 segment of the left MCA. Fluoroscopic post-procedural image confirmed a correct flow diverter position resulting in complete aneurysm occlusion with no signs of further recurrence (Fig. 4).

The patient recovered well, with residual mild right-sided motor weakness. She was thoroughly followed-up both clinically and radiologically, while antiaggregation therapy was continued for 6 months after the procedure.

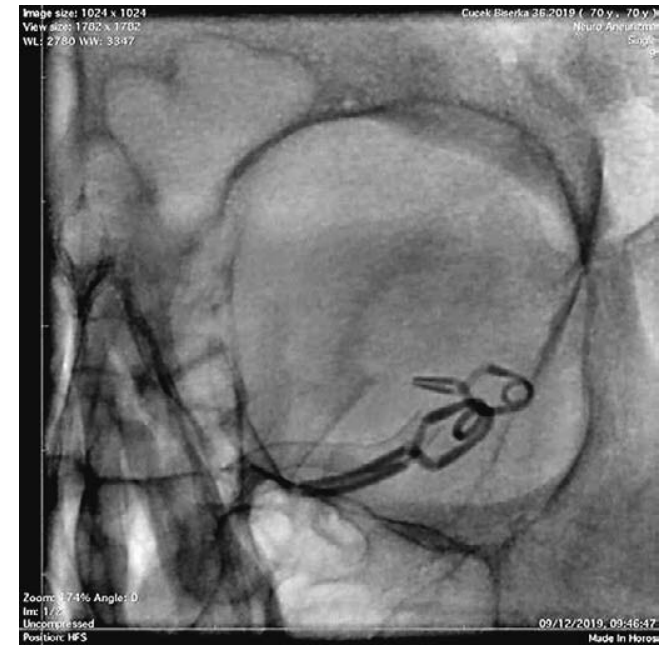

Fig. 4. Fluoroscopic post-procedural image after successful placement of Silk Vista Baby flow diverter in M1 segment of the left middle cerebral artery resulting in recurrent aneurysm complete occlusion. Aneurysmal clips from previous microsurgeries are also seen.

At six-month follow-up, brain CT angiograms were performed, showing correctly placed and patent flow diverter in the left M1 segment and patent distal MCA branches, as well as complete aneurysm occlusion with no signs of recurrence (Fig. $5 \mathrm{a}, \mathrm{b}$ ).

Further scrupulous clinical follow-up and magnetic resonance angiography (MRA) at one year were recommended to exclude possible aneurysm fundus revascularization. 

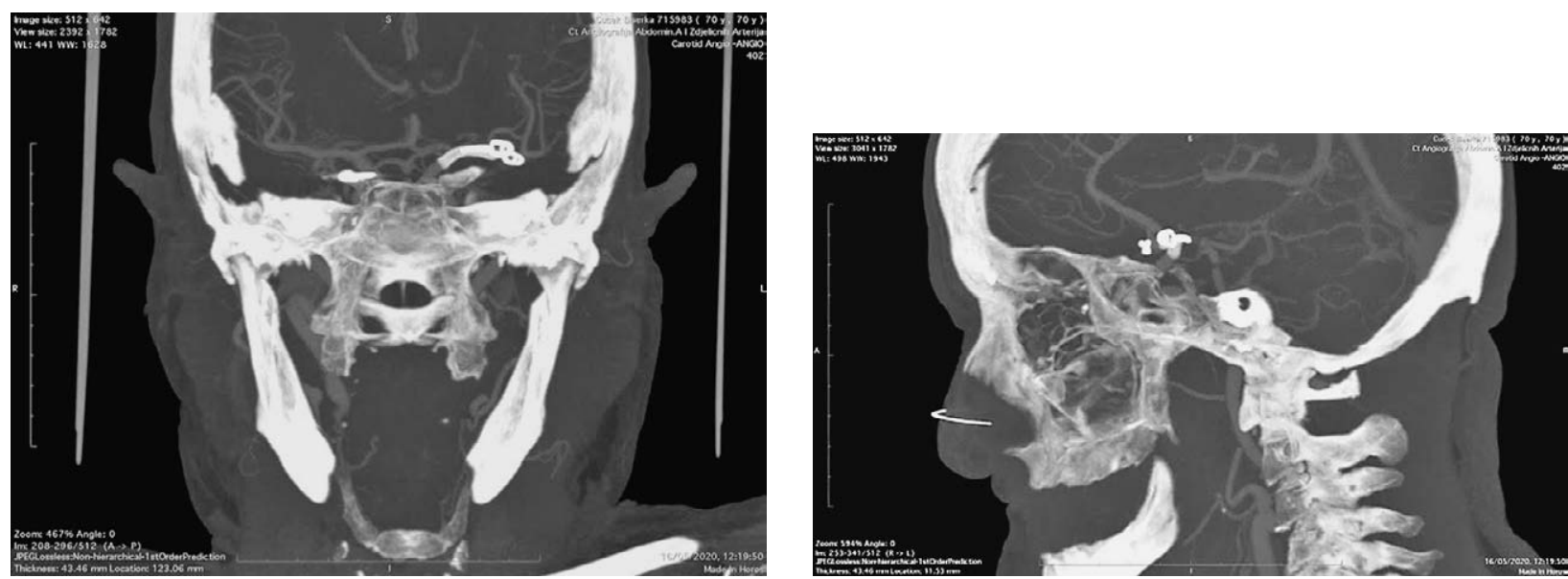

Fig. 5. Control brain computed tomography angiograms in coronal (a) and lateral (b) reformations, performed at six months after endovascular procedure, show correctly placed and patent flow diverter in the left M1 segment, and patent distal middle cerebral artery branches, as well as complete aneurysm occlusion with no signs of recurrence. Aneurysmal clips from previous microsurgeries are also seen.

\section{Discussion}

The pathophysiology of cerebral aneurysm formation includes both hemodynamic and oxidative stress. Factors responsible for inducing such stresses are numerous, including carotid artery occlusion, arterial hypertension, cerebral bypass or anatomic variations in the circle of Willis ${ }^{10,14,15}$, as well as vascular changes (endothelial dysfunction) leading to a defect of the arterial medial wall or elastic lamina. Various degenerative disorders, trauma, heritable connective-tissue diseases (e.g., Ehlers-Danlos syndrome, Marfan syndrome, fibromuscular dysplasia), and autosomal dominant polycystic kidney disease may be involved too ${ }^{16-18}$.

Multiple cerebral aneurysms arise in $17 \%-32 \%$ of cases $^{18-20}$, and they tend to relapse more often than the solitary ones. However, very few patients may grow an entirely new (de novo) intracranial aneurysm after a successful initial management during a long-term follow-up ${ }^{20}$, although an association between multiple aneurysms and de novo aneurysm formation has been reported $^{21,22}$.

Aneurysm recurrence/de novo formation may occur after initial treatment at bifurcation of basal intracranial arteries due to the specific mechanical stress and/ or incomplete primary occlusion ${ }^{23}$. Several factors such as aneurysm bigger size, complex shape, multiplicity, and unfavorable location, as well as younger age, female gender, smoking habits, and family history of the disease could be associated with the higher prevalence of aneurysm relapse $4,7,10,11,24,25$.

Smoking is a well-known risk factor of aneurysm formation and recurrence due to its tendency to cause an elastase and alpha antitrypsin imbalance, which can increase the effects of hemodynamic stress on aneurysm wall ${ }^{10}$. Even though there is no clear explanation, female gender is a prominent risk factor for such formation and recurrence due to the evident high female to male ratio of $5: 1^{21}$. Previously, it has been shown that patient age as an independent risk factor plays an important role, since younger age at first aneurysm diagnosis was significantly associated with aneurysm recurrence $^{26}$. In addition, substantial predictors of procedural complications and recurrence are neck incomplete occlusion, arterial hypertension, and diabetes ${ }^{27}$. However, the exact common interaction of all these factors of relapse remains unknown. Accordingly, our female patient with a big MCA aneurysm relapse was a fervent smoker with a history of arterial hypertension, although she was not very young at the first presentation, having positive family history of the disease. She was also harboring multiple aneurysms at initial presentation.

When MCA aneurysm is concerned, microsurgical clipping remains the choice of primary treatment, having improved overall efficacy of complete occlusion ${ }^{28}$. However, since a recurrence may still occur, the best modality for aneurysm retreatment continues to be 
controversia ${ }^{29}$. Therefore, recurrent aneurysms frequently require a tailored individual approach, as well as close collaboration and mutual efforts of interdisciplinary team consisting of a neurosurgeon and neurointerventionist/radiologist to enhance aneurysm treatment ${ }^{23}$. Hence, the management of our patient was a fine example of such a team work.

A broad armamentarium of diverse endovascular procedures is currently available ${ }^{30}$. To attain the appropriate reconstruction of the parent artery after aneurysm relapse following prior microsurgical clipping, flow-diverting stents such as a microcatheter-delivered Pipeline embolization device are increasingly in use, delivering a high rate of complete occlusion with minimal morbidity ${ }^{27,29,31}$. Hence, this method has become contemporary choice for the management of certain intracerebral aneurysms, including those that relapse ${ }^{32}$. However, the particular suitability of flow diverting has to be individually justified, taking into account the aneurysm geometry, procedure risk and experience of the personnel ${ }^{32}$.

The Pipeline for Uncoilable or Failed Aneurysms trial demonstrated that occlusion rates for both flow diversion and microsurgical clipping are almost the same at long-term follow-up ${ }^{33}$. Considering our patient, we used the new low-profile SVB flow diverter, which was proved feasible and technically safe, providing complete occlusion of the relapsed aneurysm ${ }^{34}$.

Although aneurysm recurrence has been reported to appear during a period ranging from several months to years following successful treatment ${ }^{4,7-9}$, the occurrence delayed by more than 20 years is rather unusual. Therefore, we believe that the extended period of 30 years between the initial surgery and aneurysm relapse found in our patient is a rare event. Considering this, the need for a routine long-term follow-up has been controversial. Several studies proposed continuing screening for aneurysm recurrence/de novo formation in all patients diagnosed with intracranial aneurysms $s^{3,7,22,35}$. Other studies proposed screening only in patients with a history of previous subarachnoid hemorrhage, hypertension, smoking, and multiple aneurysms $^{36}$. On the contrary, based on less than $2 \%$ annual risk of aneurysm relapse, some studies do not advocate continuous follow-up at all ${ }^{21}$. Still, screening at 5, 10, and 20 years could detect $31 \%, 64 \%$ and $96 \%$ of aneurysm relapses, respectively, which warrants lifelong surveillance after clipping ${ }^{7,37}$. Therefore, we support routine screening, which is recommended for microsurgically treated aneurysms in spite of a very low risk of postoperative residuals after complete aneurysm clipping ${ }^{37,38}$.

In conclusion, aneurysm recurrence is uncommon, but it can be found up to 20 years after the initial aneurysm occurrence and treatment. In our patient, delayed aneurysm relapse occurred 30 years after successful microsurgical clipping. Accordingly, one should always consider the possibility of intracranial aneurysm recurrence regardless of the mode and time of primary surgery. In such a case, it seems that a multidisciplinary management approach using flow diverting endovascular techniques currently is the best method advised in selected patients. To support our conclusions, additional evaluation of this objective on a wider sample and a systematic literature review are needed.

\section{References}

1. Graf C, Hamby WB. Report of a case of cerebral aneurysm in an adult developing apparently de novo. J Neurol Neurosurg Psychiatry. 1964;27:153-6. doi: 10.1136/jnnp.27.2.153.

2. Giordan E, Brinjikji W, Vine RL, Lanzino G. Risk of de novo aneurysm formation in patients with unruptured intracranial aneurysms. Acta Neurochir (Wien). 2018;160(4):747-51. doi: 10.1007/s00701-018-3472-5.

3. Kemp WJ III, Fulkerson DH, Payner TD, Leipzig TJ, Horner TG, Palmer EL, et al. Risk of hemorrhage from de novo cerebral aneurysms. J Neurosurg. 2013;118:58-62. doi: 10.3171/ 2012.9.JNS111512.

4. Matheus MG, Castillo M. Development of de novo intracranial aneurysm in three months: case report and literature review. AJNR Am J Neuroradiol. 2003;24(4):709-10.

5. Rahmah NN, Horiuchi T, Kusano Y, Sasaki T, Hongo K. De novo aneurysm: case reports and literature review. Neurosurgery. 2011;69:E761-E766. doi: 10.1227/NEU.0b013e3182 196489.

6. Sprengers ME, van Rooij WJ, Sluzewski M, Rinkel GJ, Velthuis BK, de Kort GA, et al. MR angiography follow-up 5 years after coiling: frequency of new aneurysms and enlargement of untreated aneurysms. AJNR Am J Neuroradiol. 2009; 30:303-7. 2009;30:303-7. doi: 10.3174/ajnr.A1353.

7. Spiessberger A, Vogt DR, Fandino J, Marbacher S. Formation of intracranial de novo aneurysms and recurrence after neck clipping: a systematic review and meta-analysis. J Neurosurg. 2019;132(2):456-64. doi: 10.3171/2018.10.JNS181281.

8. Hokari M, Kazumara K, Nakayama N, Ushikoshi S, Sugiyama $\mathrm{T}$, Asaoka $\mathrm{K}$, et al. Treatment of recurrent intracranial aneurysms after clipping: a report of 23 cases and a review of the 
literature. World Neurosurg. 2016;92:434-44. doi: 10.1016/j. wneu.2016.05.053.

9. Rothemeyer S, Lefeuvre D, Taylor A. Recurrent or new symptomatic cerebral aneurysm after previous treatment. Interv Neuroradiol. 2005;11(4):341-8. doi: 10.1177/159101990501 100406.

10. Juvela S, Poussa K, Porras M. Factors affecting formation and growth of intracranial aneurysms: a long-term follow-up study. Stroke. 2001;32:485-91. doi: 10.1161/01.str.32.2.485.

11. Lai LT, Morgan MK, Patel NJ. Smoking increases the risk of $d e$ novo intracranial aneurysms. World Neurosurg. 2014;82:e195201. doi: 10.1016/j.wneu.2014.02.002.

12. Lather HD, Gornik HL, Olin JW, Gu X, Heidt ST, Kim ESH, et al. Prevalence of intracranial aneurysm in women with fibromuscular dysplasia: a report from the US registry for fibromuscular dysplasia. JAMA Neurol. 2017;74(9):1081-7. doi: 10.1001/jamaneurol.2017.1333.

13. Schebesch KM, Doenitz C, Zoephel R, Finkenzeller T, Brawanski AT. Recurrent subarachnoid hemorrhage caused by a de novo basilar tip aneurysm developing within 8 weeks after clipping of a ruptured anterior communicating artery aneurysm: case report. Neurosurgery. 2008;62:E259-E260. doi: 10.1227/01.NEU.0000311087.19261.0A.

14. Arambepola PK, McEvoy SD, Bulsara KR. De novo aneurysm formation after carotid artery occlusion for cerebral aneurysms. Skull Base. 2010;20:405-8. doi: 10.1055/s-0030-1253578.

15. Fukushima Y, Miyawaki S, Inoue T, Shimizu S, Yoshikawa G, Imai $\mathrm{H}$, et al. Repeated de novo aneurysm formation after anastomotic surgery: potential risk of genetic variant RNF213 c.14576G>A. Surg Neurol Int. 2015;6:41. doi: 10.4103/21527806.153709 .

16. Chauveau D, Sirieix ME, Schillinger F, Legendre C, Grünfeld JP. Recurrent rupture of intracranial aneurysms in autosomal dominant polycystic kidney disease. BMJ. 1990;301:966-7. doi: 10.1136/bmj.301.6758.966.

17. Krex D, Scharckert HK, Scharkert G. Genesis of cerebral aneurysm: an update. Acta Neurochir (Wien). 2001;143:429-49. doi:10.1007/s007010170072.

18. Juvela S, Porras M, Poussa K. Natural history of unruptured intracranial aneurysms: probability of and risk factors for aneurysm rupture. J Neurosurg. 2000;93:379-87. doi: 10.3171/ jns.2000.93.3.0379.

19. Rinkel GJ, Djibuti M, Algra A, van Gijn J. Prevalence and risk of rupture of intracranial aneurysms: a systematic review. Stroke. 1998;29:251-6. doi: 10.1161/01.str.29.1.251.

20. Rinne JK, Hernesniemi JA. De novo aneurysms: special multiple intracranial aneurysms. Neurosurgery. 1993;33:981-5. doi: 10.1227/0000612319931200000004.

21. David CA, Vishteh AG, Spetzler RF, Lemole M, Lawton MT, Partovi S. Late angiographic follow-up review of surgically treated aneurysms. J Neurosurg. 1999;91:396-401. doi: 10.3171/jns.1999.91.3.0396.

22. Zali A, Khoshnood RJ, Zarghi A. De novo aneurysms in longterm follow-up computed tomographic angiography of pa- tients with clipped intracranial aneurysms. World Neurosurg. 2014;82:722-5. doi: 10.1016/j.wneu.2013.06.008.

23. Mueller OM, Schlamann M, Mueller D, Sandalcioglu IE Forsting M, Sure U. Intracranial aneurysms: optimized diagnostic tools call for thorough interdisciplinary treatment strategies. Ther Adv Neurol Disord. 2011;4(5):267-79. doi: 10.1177 /1756285611415309.

24. Backes D, Rinkel GJE, Greving JP, Velthuis BK, Murayama Y, Takao H, et al. ELAPSS score for prediction of risk of growth of unruptured intracranial aneurysms. Neurology. 2017;88: 1600-6. doi: 10.1212/WNL.0000000000003865.

25. Leblanc R. De novo formation of familial cerebral aneurysms: case report. Neurosurgery. 1999;44:871-6. doi: 10.1097/ 00006123-199904000-00110.

26. Lindgren AE, Räisänen S, Björkman J, Tattari H, Huttunen J, Huttunen $\mathrm{T}$, et al. De novo aneurysm formation in carriers of saccular intracranial aneurysm disease in eastern Finland. Stroke. 2016;47:1213-8. doi: 10.1161/STROKEAHA.115.012573.

27. Silva MA, See AP, Khandelwal P, Mahapatra A, Frerichs KU, Rose $\mathrm{R}$, et al. Comparison of flow diversion with clipping and coiling for the treatment of paraclinoid aneurysms in $115 \mathrm{pa}^{-}$ tients. J Neurosurg. 2018;1-8. doi: 10.3171/2018.1.JNS171774.

28. Smith TR, Cote DJ, Dasenbrock HH, Hamade YJ, Zammar $\mathrm{SG}, \mathrm{El}$ Tecle NE, et al. Comparison of the efficacy and safety of endovascular coiling versus microsurgical clipping for unruptured middle cerebral artery aneurysms: a systematic review and meta-analysis. World Neurosurg. 2015;84(4):942-53. doi: 10.1016/j.wneu.2015.05.073.

29. Dornbos D 3rd, Karras CL, Wenger N, Priddy B, Youssef P, Nimjee SM, et al. Pipeline embolization device for recurrence of previously treated aneurysms. Neurosurg Focus. 2017; 42(6):E8. doi: 10.3171/2017.3.FOCUS1744.

30. Kalousek V, Splavski B, Beroš V, Čulo B, Vrban F, Rotim A, Rotim K.Large aneurysm of basilar artery tip mimicking midbrain tumor and causing unilateral obstructive hydrocephalus: a case report and a technical note. Acta Clin Croat. 2020;59: 166-72. doi: 10.20471/acc.2020.59.01.21.

31. Lylyk P, Miranda C, Ceratto R, Ferrario A, Scrivano E, Ramirez Luna $\mathrm{H}$, et al. Curative endovascular reconstruction of cerebral aneurysms with the pipeline embolization device: the Buenos Aires experience. Neurosurgery. 2009;64(4):632-42. doi: 10.1227/01.NEU.0000339109.98070.65.

32. Dmytriw AA, Phan K, Moore JM, Pereira VM, Krings T, Thomas AJ. On flow diversion: the changing landscape of intracerebral aneurysm management. AJNR Am J Neuroradiol. 2019; 40(4):591-600. doi: https://doi.org/10.3174/ajnr.A600.

33. Becske T, Brinjikji W, Potts MP, Kallmes DF, Shapiro M, Moran CJ, et al. Long-term clinical and angiographic outcomes following pipeline embolization device treatment of complex internal carotid artery aneurysms: five-year results of the Pipeline for Uncoilable or Failed Aneurysms trial. Neurosurgery. 2017;80(1):40-8. doi: 10.1093/neuros/nyw014. 
34. Martínez-Galdámez M, Biondi A, Kalousek V, Pereira VM, Ianucci G, Gentric JC, et al. Periprocedural safety and technical outcomes of the new Silk Vista Baby flow diverter for the treatment of intracranial aneurysms: results from a multicenter experience. J Neurointerv Surg. 2019;11(7):723-7. doi: 10.1136/ neurintsurg-2019-014770.

35. Tsutsumi K, Ueki K, Morita A, Usui M, Kirino T. Risk of aneurysm recurrence in patients with clipped cerebral aneurysms: results of long-term follow-up angiography. Stroke. 2001;32 (5):1191-4. doi: 10.1161/01.str.32.5.1191.

36. Wermer MJ, Rinkel GJ, Greebe P, Albrecht KW, Dirven CM, Tulleken CA. Late recurrence of subarachnoid hemorrhage af- ter treatment for ruptured aneurysms: patient characteristics and outcomes. Neurosurgery. 2005;56:197-204. doi: 10.1161/ 01.STR.0000185686.28035.d2.

37. Burkhardt JK, Chua MHJ, Weiss M, Do ASS, Winkler EA, Lawton MT. Risk of aneurysm residual regrowth, recurrence, and de novo aneurysm formation after microsurgical clip occlusion based on follow-up with catheter angiography. World Neurosurg. 2017;106:74-84. doi: 10.1016/j.wneu.2017.06.110.

38. Brown MA, Parish J, Guandique CF, Payner TD, Horner T, Leipzig $\mathrm{T}$, et al. A long-term study of durability and risk factors for aneurysm recurrence after microsurgical clip ligation. J Neurosurg. 2017;126(3):819-24. doi: 10.3171/2016.2.JNS152059.

Sažetak

\title{
KASNI NASTANAK RECIDIVIRAJUĆE ANEURIZMATSKE TVORBE NAKON MIKROKIRURŠKOG LIJEČENJA ANEURIZME SREDNJE MOŽDANE ARTERIJE: PRIKAZ SLUČAJA I PREGLED LITERATURE O MOGUĆNOSTIMA LIJEČENJA
}

\author{
K. Rotim, M. Raguž, A. Rotim, B. Splavski i V. Kalousek
}

Kasni nastanak recidivirajuće intrakranijske aneurizmatske tvorbe nakon mikrokirurškog liječenja je neuobičajen. Iako točna etiologija ostaje nepoznata, recidiv aneurizme može nastati u kirurških bolesnika s velikim i višekratnim aneurizmama, arterijskom hipertenzijom, neaterosklerotičkom cerebrovaskularnom arteriopatijom, kao i onih s obiteljskom anamnezom u povijesti bolesti. Recidivirajuća se aneurizma može očitovati tijekom dužeg razdoblja, u rasponu od nekoliko mjeseci do nekoliko godina nakon inicijalnog liječenja. Ipak, kasni nastanak aneurizme u vremenu dužem od 20 godina prilično je rijedak. U ovom radu prikazujemo slučaj 70-godišnje bolesnice s recidivirajućom aneurizmom srednje moždane arterije nastalom 30 godina nakon uspješnog mikrokirurškog liječenja. Također donosimo kratak pregled relevantne literature koja govori o etiologiji i patofiziologiji nastanka recidivirajuće aneurizme, kao i o različitim raspoloživim mogućnostima liječenja. Zaključujemo kako uvijek treba voditi računa o mogućnosti nastanka recidivirajuće intrakranijske aneurizme neovisno o načinu liječenja i vremenu proteklom od prvobitnog kirurškog zahvata. U ovakvom se slučaju preporuča multidisciplinarni pristup primjenom metode endovaskularnog preusmjerenog protoka kao najprimjerenije suvremene tehnike u odabranih bolesnika.

Ključne riječi: Aneurizma, intrakranijska; Kasni recidiv; Liječenje, mikrokirurško i endovaskularno 